\title{
ФОРМУВАННЯ ГОТОВНОСТІ МАЙБУТНІХ УЧИТЕДІВ ПРИРОДНИЧИХ НАУК ДО ІННОВАЦІЙНОЇ ДІЯЛЬНОСТІ
}

У статті на основі аналізу літературних джерел та досвіду власної педагогічної діяльності розроблено та апробовано методику формування готовності майбутніх учителів природничих наук до інноваційної діяльності як ефективного механізму впливу на розвиток їхнвої професійної компетентності, яка поєднуе традиційні та інноваційні форми $і$ засоби навчання. Вона передбачае використання інтегрованої методичної платформи вчителів природничого циклу, на якій створено нові методичні структури, через які здійснюється менеджмент освітніх інновацій серед майбутніх учителів природничих наук, застосовуючи інноваційні форми роботи. Ї̈̈ провідна ідея полягае у доцільності урізноманітнення засобів формування готовності майбутніх учителів до інноваційної діяльності. Для ї̈ впровадження використовувались теоретичні та емпіричні методи.

Визначено готовність майбутніх вчителів природничих наук до інноваційної діяльності. На основі аналізу теорії та практики навчання виокремлено засоби підготовки майбутніх учителів до здобуття інноваційної компетентності: вивчення навчальних дисизиплін «Методика наукових досліджень» та «Формування інноваційної культури вчителя». Описано технологію розробки та сутність відповідних авторських програм. Охарактеризовано специифіку проведення вебінарів: “Що таке Квізі $і$ як адаптувати його в освітній процес»; «Вернісаж педагогічних ідей»; методичної майстерки «Урок мислення на природі (Орепairclassroom)»; студї професійної інтернатури; педагогічної майстерні «нноваційна мобільність - 2021»; майстер-класу "Професійний розвиток вчителя»; онлайн-конференцій «Технологія дистанційного навчання як стратегія оновлення компетентнісно-орієнтованого освітнвого середовищца» тощо. Зроблено висновок про ефективність використання зазначених форм навчальних занять.

Ключові слова: підготовка вчителя, природничі науки, методика, інноваційна діяльність, методична платформа.

Постановка проблеми. Однією з кдючових освітянських подій останніх років є прийняття нормативних документів, які стади основою освітянських реформ. Так, у «Професійному стандарті за професіями «Вчитель початкових класів закладів загальної середньої освіти», «Вчитель закладів загальної середньої освіти», «Вчитель 3 початкової освіти (з дипломом молодший спеціаліст)» [7] серед переліку трудових функцій визначено таку, як безперервний професійний розвиток. П̈і виконання передбачає поряд з іншими і сформованість інноваційної компетентності. Це актуалізує тему нашої публікації.

Аналіз досліджень. У науково-педагогічній літературі існуе апробований досвід упровадження компетентнісного підходу як основи організації та здійснення освітнього процесу в педагогічних закладах вищої освіти (В. Бондар, О. Коваленко, О. Малихін,

*C) Козловська Л. П.

*C) Степанюк А. В.

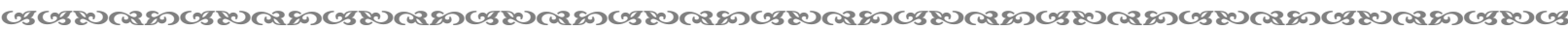
102 
О. Пометун, С. Сисоєва, А. Степанюк, О. Топузов та ін.) [1-4]. Організація та здійснення освітнього процесу з підготовки майбутніх учителів із застосуванням інформаційних технологій розкриваються в працях В. Бикова, Л. Міронець, Н. Морзе, Р. Тарасенка, А. Степанюк, І. Цідило та ін. [8].

Як стверджують науковці, провідна роль серед загальнометодологічних підходів до створення й реалізації системи розвитку інноваційної компетентності педагогів належить системно-синергетичному підходу (М. Артюшина, І. Афанасьєв, В. Беспалько, І. Блауберг, О. Вознюк, Б. Гершунський, Н. Гузій, О. Дубасенюк, В. Кремень, В. Аутай, М. Радченко, Е. Юдін та ін.) [1;3; 4].

Проблемі підготовки вчителів природничої галузі знань присвячені дослідження таких науковців, як Л. Барна, Л. Благодаренко, О. Варакута, М. Гладюк, Н. Грицай, М.Декарчук, Г.Жирська, Т. Засекіна, М. Мартинюк, В. Мацюк, Н. Міщук, Т. Олендр, Н. Підопригора, Л. Покась, А. Степанюк, I. Ткаченко, О. Цуруль та ін. [5; 8; 9]. У їх доробку висвітлені проблеми фундаменталізації та інтеграції змісту природничої освіти, формування ціннісного компонента змісту освіти, інноваційні технології навчання, історія становлення проблеми підготовки вчителів природничих наук. Однак, проблема формування готовності майбутніх учителів природничих наук до інноваційної діяльності не отримала ще достатнього опрацювання.

Мета статті: на основі аналізу літературних джерел та досвіду власної педагогічної діяльності розробити методику формування готовності майбутніх учителів природничих наук до інноваційної діяльності та адаптувати їі до умов змішаної форми навчання.

Виклад основного матеріаду. Визначення засобів підготовки майбутніх учителів природничих наук до здобуття інноваційної компетентності ми розпочали 3 анадізу практики. Зокрема, з визначення рівня готовність майбутніх вчителів до інноваційної діяльності.

Проведено моніторингове дослідження рівня сформованості готовності 120 здобувачів другого (магістерського) рівня вищої освіти спеціальностей 014. Середня освіта (Природничі науки), (Біологія та здоров'я людини) та вчителів навчальних предметів освітньої галузі «Природознавство» 3 досвідом педагогічної діядьності до 5 років до інноваційної діяльності. Така різноманітність вибірки пояснюеться незначною кількістю здобувачів ОПП Середня освіта (Природничі науки).

Чи відчуваєте ви себе готовими до освоєння нововведень:

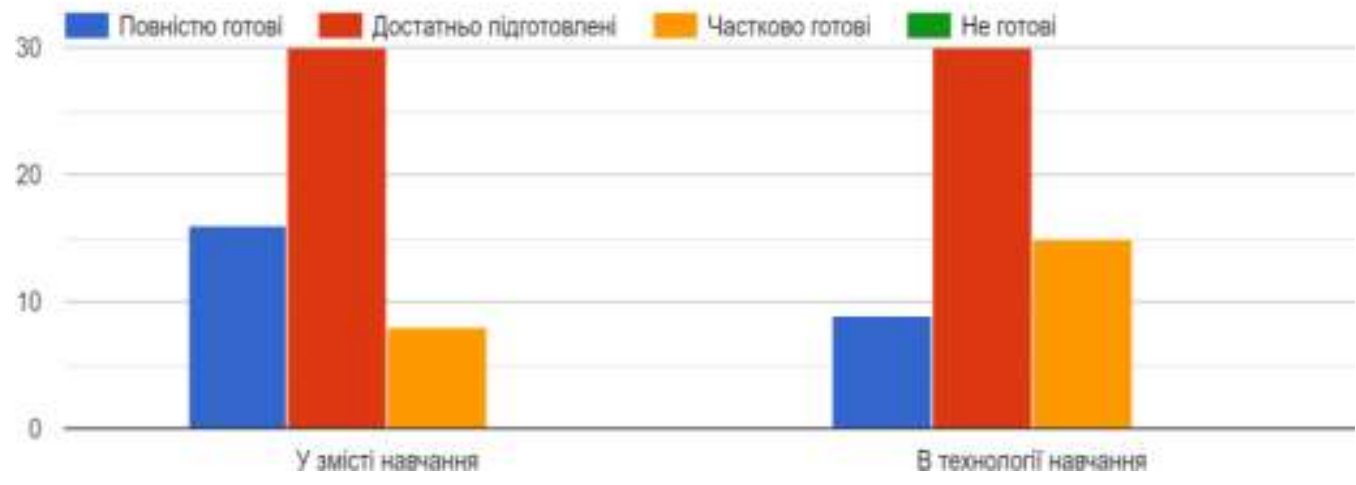

Рис. 1. Самооцінка готовності респондентів до освоєння нововведень (54 респонденти) 
Зокрема, результати самооцінки готовності до інноваційної діяльності (рис. 1) засвідчиди, що повністю готові до впровадження інновацій у зміст освіти 16 осіб (29,6 \%), 30 осіб (55,5\%) - достатньо підготовлені, а 8 осіб (14,9\%) - частково готові. Результати отримані щодо впровадження інновацій щодо технологій навчання такі: 9 осіб (16,7 \%) повністю готові до впровадження інновацій у зміст навчання; 30 осіб (55,5 \%) - достатньо підготовлені, 15 осіб (27,8 \%) - частково готові. Отже, менша кількість респондентів повністю готова і більша їх кількість частково готова до впровадження інновацій у технології навчання, ніж у зміст навчання.

До перешкод в освоєнні та розробці нововведень (рис. 2) більшість респондентів відносять відсутність часу та належного стимудювання, недостатність необхідних теоретичних знань та допомоги з боку досвідчених педагогів. Щодо готовності респондентів до створення власного авторського досвіду з використання інновацій у процесі вивчення природничих наук (рис. 3), то їх самоаналіз засвідчив, що 43,4 \% воліють використовувати чужий досвід і при цьому прагнуть до стабільності, 37,7 \% відчувають себе готовими до впровадження інноваційних технологій, 15,1\% - дише у зміст навчання.

\section{Що є для вас перешкодою в освоєнні і розробці нововведень? (виберіть 5 найбільш значущих для вас перешкод) \\ 548nbsp;oтвета}

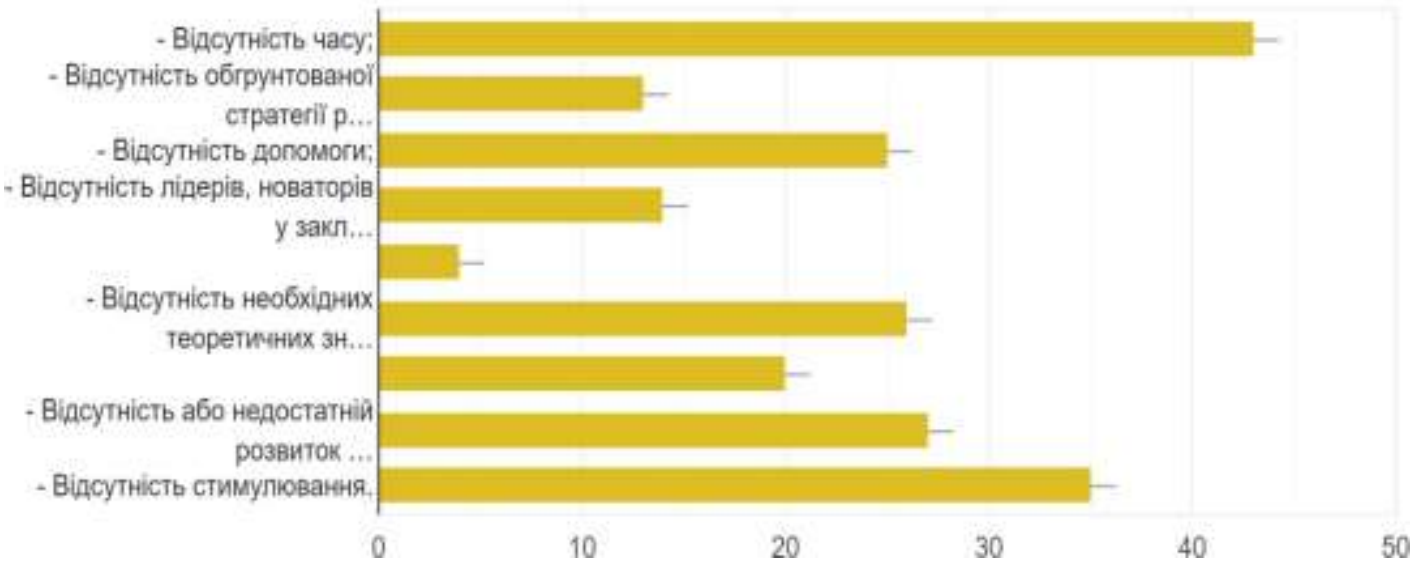

Рис. 2. Перешкоди в освоєнні та розробці нововведень

\section{Чи відчуваєте ви себе готовим до створення власного авторського дасвіду \\ 538 nbsp,oтвета}

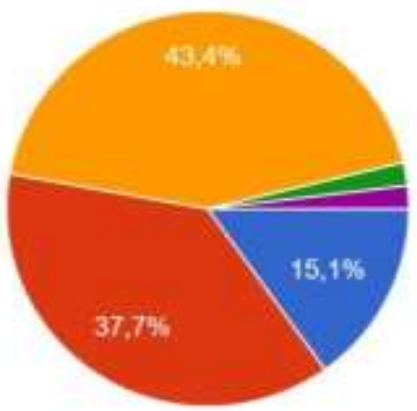

у змісті навчання

в технологіi навчанне

ні, вопіко використовувати чужий досеід , прапну до стабіпьності

- Вивчивши передовий досвід колег. можна спробувати запровадити його у власній діяльності (за підтримки)

Поки ноо не маю досаіду, готова працовати

Рис. З. Готовність до створення власного авторського досвіду (на основі самоаналізу) 
На запитання щодо доцільності змін в освітньо-професійній програмі підготовки здобувачів другого (магістерського) рівня вищої освіти (рис. 4) 68,5\% респондентів зазначили необхідність змін у технологіях навчання, виховання та розвитку і лише 9,3\% опитаних у своїх відповідях зазначили доцільність змін в управлінні ЗВО.

\section{Які, на ваш погляд, конкретні зміни потрібні у вашому закладі освіти ? 54\&nbsp;oтвета}
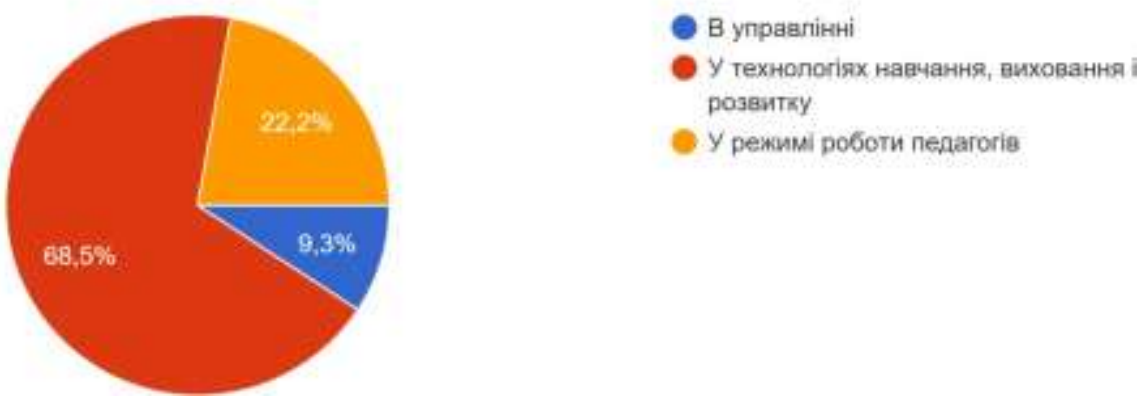

Рис. 4. Доцільність змін у освітньо-професійних програмах підготовки здобувачів другого (магістерського) рівня вищцої освіти

Результати опитування засвідчиди, що у відповідях на запитання «Чи задоволені Ви мотиваційними заходами закладів освіти?» 61,3\% респондентів дали відповідь «Переважно так», $33 \%$ задоволені мотиваційними заходами і лише 5,7 опитаних відповіли «переважно ні» або «ні».

На основі отриманих даних ми зробили висновок, що експериментальна методика має максимально враховувати потребу респондентів у формуванні готовності до впровадження інновацій у технології навчання та надавати необхідний об'єм теоретичних знань, які сприяють формуванню готовності до впровадження педагогічних інновацій. Саме на реалізацію цих завдань і спрямована наша методика.

На основі аналізу теорії та практики навчання [6;7] нами виокремлено засоби підготовки майбутніх учителів до здобуття інноваційної компетентності. Ними є вивчення навчальних дисциплін «Методика наукових досліджень» та «Формування інноваційної культури вчителя природничих наук». Зупинимось на висвітденні сутності другої експериментальної дисципліни «Формування інноваційної кудьтури вчителя природничих наук». Під час іï розробки ми використали інтегровану платформу вчителів природничого циклу, яка функціонуе при Тернопільському комунальному методичному центрі науково-освітніх інновацій та моніторингу. В такий спосіб адаптувади нашу методику до умов змішаного навчання. Це дозволило вирішити проблему науково-методичної забезпечення умов дия модернізації курсів природничого циклу на засадах освітніх інновацій та стимудювання до самоосвітньої діяльності педагогів. Одним із напрямів іiі діяльності є формування готовності вчителів до інноваційної діяльності. Координуе роботу платформи $А$. Коздовська. На базі цієї платформи функціонуе 2 сайти і 2 блоги.

Сайти:

1) Біологія/хімія, основи здоров'я (https://bioxima.wordpress.com/).

2) Сайт учителів географіï https://geotern.wixsite.com/geografiya Блоги:

1.Д. Коздовська: консультант 3 біології, географії, основ здоров'я (https://www.blogger.com/blog/posts/3382424947403587715?tab=mj). 
2. Блог учителів біології та хімії (http://biochim2016.blogspot.com/

Створені методичні структури, кожна 3 яких має свою тематику i напрям дослідження https:http://biochim2016.blogspot.com/

План аудиторних занять із навчальної дисципліни «Формування інноваційної культури вчителя природничих наук» (3 кредити) подано в таблиці 1. Мета навчальної дисципліни - формувати у майбутніх учителів основи інноваційної культури, підвищити їхні професійні компетентності шляхом здобуття знань і умінь відповідно до професійно-кваліфікаційних характеристик, що дає змогу забезпечити вищу якість діяльності в сучасних освітніх умовах; розвивати здатність майбутнього фахівця до творчого сприйняття і розуміння дійсності в динамічному інноваційному середовищі з урахуванням специфіки професійної діяльності.

Таблиия 1

Тематичний план навчальної дисципліни «Формування інноваційної культури вчителя природничих наук»

\begin{tabular}{|c|c|c|c|c|c|c|}
\hline \multirow{2}{*}{$\begin{array}{l}\text { № } \\
\text { пII }\end{array}$} & \multirow{2}{*}{ Назва теми } & \multicolumn{5}{|c|}{ Розподіл годин } \\
\hline & & всього & пекц. & сем. & прак. & c.p. \\
\hline 1 & 2 & 3 & 4 & 5 & 6 & 7 \\
\hline 1. & 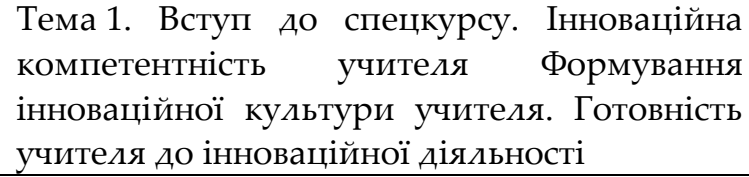 & 8 & 2 & 1 & & 5 \\
\hline 2. & $\begin{array}{l}\text { Тема 2. Інноваційні форми, методи і } \\
\text { технодогії навчання }\end{array}$ & 8 & 2 & 1 & & 5 \\
\hline 3. & $\begin{array}{l}\text { Тема 3. Кейс-уроки , як пов'язати навчання } 3 \\
\text { реальним життям }\end{array}$ & 7 & 1 & 1 & & 5 \\
\hline 4. & $\begin{array}{l}\text { Тема } 4 . \text { Як запровадити STEM на своїх } \\
\text { уроках. }\end{array}$ & 6 & 1 & 1 & & 4 \\
\hline 5. & $\begin{array}{l}\text { Тема 5. E-learning, m-learning, u-learning, f- } \\
\text { learning,blended-learning методики навчання }\end{array}$ & 6 & 1 & 1 & & 4 \\
\hline 6. & $\begin{array}{l}\text { Тема 6. Критичне та креативне мислення - } \\
\text { технології для розвитку творчих та } \\
\text { впевнених у собі особистостей }\end{array}$ & 9 & 1 & 1 & 2 & 5 \\
\hline 7. & Тема 7. Проєктна технологія & 5 & 1 & & & 4 \\
\hline 8. & Тема 8. Метод «Скрайбінг» & 5,5 & 0,5 & 1 & & 4 \\
\hline 9. & Тема 9. Метод «Fishbone» & 5,5 & 0,5 & 1 & & 4 \\
\hline 10. & $\begin{array}{l}\text { Тема 10. Метод «Storytelling» - метод цікавої } \\
\text { розповіді }\end{array}$ & 5,5 & 0,5 & 1 & & 4 \\
\hline 11. & Тема 11. Ігровий прийом «Quest» & 6,5 & 0,5 & 1 & 1 & 4 \\
\hline 12. & $\begin{array}{l}\text { Тема 12. Метод Иепбук: яскраво, творчо, } \\
\text { пізнавально }\end{array}$ & 6 & 1 & 1 & & 4 \\
\hline 13. & $\begin{array}{l}\text { Тема 13. Інтелект-карта - універсальний } \\
\text { спосіб осмислення інформації }\end{array}$ & 6 & 1 & 1 & & 4 \\
\hline 14. & Тема 14. Уроки мислення на природі & 6 & 1 & & 1 & 4 \\
\hline & Всього & 90 & 14 & 12 & 4 & 60 \\
\hline
\end{tabular}

Навчальна дисципліна передбачає виконання таких проєктів для організації самостійної діяльності студентів:

1) Використання інноваційних форм, методів і технологій навчання на уроці ( з досвіду роботи наставника, завдання для виконання на педагогічній практиці). 


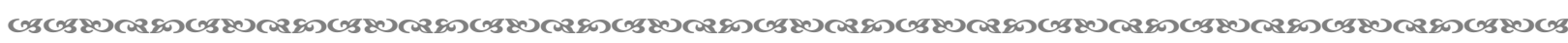
ПЕДАГОГІЧНИЙ АЛЬМАНАХ. - 2021. - ВИПУСК 50

जo

2) Інноваційно-аналітичні вміння вчителя як умова успішної професійної діяльності.

3) Розробити таблицю, схему або карту-знань сучасних технологій навчання 3 короткою анотацією кожної технології, враховуючи взаємозв'язки традиційних та інноваційних технологій навчання.

4) Написати есе (3-4 сторінки) на тему «Інноваційні підходи до навчання: зарубіжний досвід» (країна на вибір) .

5) Розробити презентацію (не менше 15 слайдів), або короткий відеородик (не менше 5 хв.) на тему «Учитель нової української школи: організація уроку». https://bioxima.wordpress.com/2020/

Експериментальна методика передбачала проведення таких форм навчальних занять: методична майстерка «Урок мислення на природі (Open-airclassroom): ефективний формат уроків у осінньо-весняний період» для охочих учителів природознавства, біології, географії, курсу «Природничі науки» та основ здоров'я; https://bioxima.wordpress.com/page/8/; воркшопи для майбутнього вчителя «Формування інтерактивного середовища Нової української шкоди через розвиток професійних компетентностей учителя», «Визначення пріоритетних форм і методів навчання сучасного фахівця в умовах формальної, неформальної та інформальної освіти»; відеоконференція на тему: «EduScrum - методика управління освітніми проєктами» http://osnovuzdorovya.blogspot.com/2020/11/eduscrum.html; вебінари: «Що таке Квіз і як адаптувати його до освітнього процесу. Ігрові технології на уроках природничого циклу та основ здоров'я» https://bioxima.wordpress.com/page/4/ та «Вернісаж педагогічних ідей»; онлайн-зустріч: «Інноваційна мобільність педагога - 2020-2021. Змінюймо разом!» https://bioxima.wordpress.com/; педагогічна майстерня на тему: «нноваційні форми організації навчальної діяльності» https://bioxima.wordpress.com/category/; засідання інтерактивної иколи сучасного вчителя: «Інновації сьогодні. Основні освітні тренди навчального року» та «Формування інтерактивного середовища сучасного уроку біології через розвиток професійних компетентностей учителя»

https://bioxima.wordpress.com/category/21;https://bioxima.wordpress.com/category/21 ; методичний кластер «Інноваційні форми організації навчальної діяльності в Інтернетсередовищі» https://bioxima.wordpress.com/category/21.

Застосування в системі зазначених форм та змісту підготовки майбутніх учителів природничих наук до інноваційної діяльності складає суть авторської методики формування готовності майбутніх учителів до інноваційної діяльності. Основним iï системотвірним чинником є мета, а саме: формування інтегральної компетентності підготовки магістрів за ОПП Середня освіта (Природничі науки). 3 метою перевірки ефективності запропонованої методики формування готовності майбутніх учителів природничих наук до інноваційної діяльності здійснювалась дослідноекспериментальна робота Вона передбачала три етапи: діагностико-коректуючий; навчальний; аналітико-регулятивний.

Після розробки методики формування готовності майбутніх учителів природничих наук до інноваційної діядьності ми проведи перший діагностуючий зріз рівня готовності майбутніх учителів до інноваційної діяльності. Перевірявся рівень сформованості мотиваційного, когнітивного, морально-вольового, гностичного, організаційного компонентів, здатність до самоуправління у педагогічній діяльності та комунікативні здібності. Після заповнення анкет підраховується загадьна кількість балів. Максимальній загальній кількості балів - 560; від 400-560 балів - високий рівень сформованості готовності; від 240-400 балів -середній; 100-240 балів - достатній; менше 100 балів - низький (інноваційна діяльність учителя фрагментарна). 
Після завершення навчання за експериментальною методикою (навчальний етап дослідження) проведено другий діагностуючий зріз. За різницею рівнів готовності робився висновок про ефективність запропонованої методики. У формувальному експерименті взяли участь 34 респонденти. Результати діагностуючого анкетування наведені в таблиці 2.

Таблиия 2

Рівень сформованості готовності до інноваційної діяльності у майбутніх учителів природничих наук

\begin{tabular}{|l|c|c|c|c|c|}
\hline \multirow{2}{*}{ Діагностичні зрізи } & \multirow{2}{*}{$\begin{array}{l}\text { К-сть } \\
\text { респ. }\end{array}$} & \multicolumn{4}{|c|}{ Рівніготовності(у \%) } \\
\cline { 3 - 6 } & 34 & 28,7 & 28,9 & 31,6 & 10,8 \\
\hline Вхідний & 34 & 32,4 & 35,2 & 32,4 & 0 \\
\hline Заключний & & $+3,7$ & $+6,3$ & +0.8 & $-10,8$ \\
\hline Різниця & &
\end{tabular}

Результати дослідження свідчать, що після впровадження експериментальної методики у 32,4\% респондентів готовність до інноваційної діяльності сформувалась на високому рівні. Це на 3,7\% більше, ніж до експериментального навчання. Значно зросли і показники кількості респондентів з середнім і достатнім рівнями. Разом з тим, кількість респондентів з низьким рівнем зменшилась з 10,8 \% до 0 \%.

Висновки. Запропонована методика формування готовності майбутніх учителів природничих наук до інноваційної діяльності $є$ ефективним механізмом впливу на розвиток професійної компетентності майбутніх учителів природничих наук. Іїі впровадження сприяе підвищенню професійної майстерності, самоосвіті, розвитку інноваційної культури майбутнього вчителя, що загалом підвищуе якість освітнього процесу. Перспективи подальших досліджень вбачаємо у визначенні ефективності кожної описаної форми організації навчальної діяльності майбутніх учителів природничих наук.

\section{Список використаних джерел:}

1. Артюшина М. В., Радченко М. І. Умови запровадження інноваційного навчання. Формування психолого-педагогічної компетентності вчителів: тренінг-курс для викладачів вищих навчальних закладів / за ред. Л. Савенкової, І. Романової. К.: НТЕУ, 2011. С. 129-143.

2. Богданова I. М. Педагогічна інноватика: навчадьний посібник. Одеса: Ранок, 2000. 148 с.

3. Ващенко $\lambda$. Інноваційні процеси в системі загальної середньої освіти особливості управління. Освіта і управління. 2003. Т. 6. № 3. С. 97-104.

4. Галіціна А. Інноваційна діяльність ЗНЗ / упоряд. А. Галіціна. Київ: ВД «Шкільний світ»: Вид. Л. Галіціна, 2005. 128 с.

5. Грицай Н. Б. Використання дистанційних технологій у методичній підготовці майбутніх учителів біології. Інформаційні технології в освіті. 2016. № 27. С. 54-66.

6. Державний стандарт базової і повної загальної середньої освіти. URL: https://zakon.rada.gov.ua/laws/show/1392-2011-\%D0\%BF

7. Професійний стандарт за професіями «Вчитель початкових класів закладів загальної середньої освіти», «Вчитель закладів загадьної середньої освіти», «Вчитель з початкової освіти (з дипломом молодший спеціаліст)». URL: https://nus.org.ua/news/zatverdyly-tryprofesijni-standart-vchytelya-dokument/

8. Степанюк А. В., Міронець $Л$. П. Методика використання веб-сайту у процесі навчання біології в основній школі. Актуальні питання природничо-математичної освіти: зб. наук. пр. / Сум. держ. пед. ун-т ім. А. С. Макаренка. Суми: СумдПУ ім. А. С. Макаренка, 2019. № 1 (13). C. 137-144. 


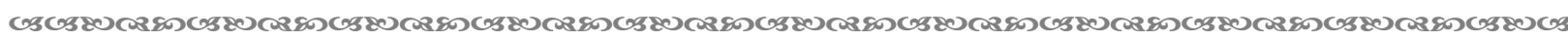
ПЕДАГОГІЧНИЙ АЛЬМАНАХ. - 2021. - ВИПУСК 50

US

9. Stepanyuk A., Olendr T. Training of Future Teachers of Natural Sciences in Pedagogical Universities of Ukraine: Realities and Prospects. Pedagogika-Pedagogy. 2019. Vol. 91. No. 9. P. 13191326.

\section{References:}

1. Artiushyna, M. V., \& Radchenko, M. I. (2011). Umovy zaprovadzhennia innovatsiinoho navchannia [Conditions for the innovative learning introduction]. Formuvannia psykholohopedahohichnoi kompetentnosti vchyteliv: treninh-kurs dlia vykladachiv vyshchykh navchalnykh zakladiv, 129-143 [in Ukrainian].

2. Bohdanova, I. M. (2000). Pedahohichna innovatyka [Pedagogical innovation studies]. Odesa: Ranok [in Ukrainian].

3. Vashchenko, L. (2003). Innovatsiini protsesy v systemi zahalnoi serednoi osvity osoblyvosti upravlinnia [Innovative processes in the system of general secondary education: features of management]. Osvita i upravlinnia, 6, 3, 97-104 [in Ukrainian].

4. Halitsina, L. (2005). Innovatsiina diialnist ZNZ [Innovative activities at the secondary schools]. Kyiv: VD «Shkilnyi svit»: Vyd. L. Halitsina [in Ukrainian].

5. Hrytsai, N. B. (2016). Vykorystannia dystantsiinykh tekhnolohii u metodychnii pidhotovtsi maibutnikh uchyteliv biolohii [Using the distance technologies in methodical training of future teachers of Biology]. Informatsiini tekhnolohii v osviti, 27, 54 - 66 [in Ukrainian].

6. State Standard of Basic and Complete General Secondary Education. Retrieved from https://zakon.rada.gov.ua/laws/show/1392-2011-\%D0\%BF [in Ukrainian].

7. Professional Standard for Teachers "Primary school teacher of general secondary education institutions", "Teacher of general secondary education institutions", "Primary education teacher (with a diploma of junior specialist)". Retrieved from https://nus.org.ua/news/zatverdyly-tryprofesijni-standart-vchytelya-dokument/ [in Ukrainian].

8. Stepanyuk, A. V., \& Mironets, L. P. (2019). Metody kavykorystanniaveb-saitu u protses inavchannia biolohii $\mathrm{v}$ osnovnii shkoli [The methodology of using the website in the process of teaching Biology in a primary school]. Aktualni pytannia pryrodnycho-matematychnoi osvity, 1 (13), 137- 144 [in Ukrainian].

9. Stepanyuk, A., \& Olendr, T. (2019). Training of Future Teachers of Natural Sciences in Pedagogical Universities of Ukraine: Realities and Prospects. Pedagogika-Pedagogy, 91, 9, 1319-1326 [in English].

Kozlovska L. P., orcid.org/0000-0001-6058-5889

StepanyukA.V.,

orcid.org/0000-0003-3258-9182

\section{THE FORMATION OF READINESS OF FUTURE SCIENCE TEACHERS FOR INNOVATIVE ACTIVITY}

The technique of formation readiness of future science teachers' readiness to innovative activity based on the analysis of literary sources and own educational experience is proposed in the research. The technique has been worked out and tested while combining traditional and innovative means of training and proved to be the effective mechanism of influence on the professional development and competence of future teachers of natural sciences.

The management of education innovations among future teachers' of natural cycle is conducted through an integrated methodological platform with updated methodological structures, using innovative forms of work. Its leading idea is the viability of diversifying the means of future teachers' readiness for innovation.Theoretical and empirical methods were used for its implementation. The readiness of future teachers of natural sciences for innovative activity is determined.

The means of future teachers' preparation for innovative competence acquisition are singled out on the basis of the analysis of the theory and practice of teaching: study of the disciplines "Methods of Scientific Research» and "Formation of the Innovative Culture of Teachers». The technology of development and the content of the corresponding author's programs are described.The peculiarities 
of the conducted webinars are defined: "What a Quiz is and How to Adapt It to the Educational Process»; "Vernissage of Pedagogical Ideas»; methodical workshop "Open-air Lesson of Thinking»; professional internship studios; pedagogical workshop «Innovative Mobility - 2021»; master class «Professional Development of a Teacher»;online conference «Distance Learning Technology as a Strategy for Updating Competency-Oriented Educational Environment» etc. The conclusion about the effectiveness of the use of mentioned forms of training is made. platform.

Key words: teacher training, natural sciences, technique, innovative activity, methodical

Дата надходженнястатті: 04.11.2021 p.

Рецензент: доктор педагогічних наук, доцент Примакова В. В.

\section{МІЖДИСЦИПЛІНАРНА ОРГАНІЗАЦІЯ РОЗВИВАЯЬНОГО ОСВІТНЬОГО СЕРЕДОВИЩА В СИСТЕМІ ПІДГОТОВКИ МАЙБУТНІХ ФАРМАЦЕВТІВ}

У статті розглянуто питання освітнвого та розвивального середовищза навчального закладу в процесі підготовки спеціалістів фармацевтичної галузі. Проаналізовано наукові та методичні джерела з питань забезпечення розвивального характеру освітнвого середовища вищої освіти у процесі використання міждисциилхінарного підходу до навчання. Розкрито основні позицї навчального процесу, що стосуються фармацевтичної сфери діяльності майбутніх випускників; підкреслено роль міждисциилінарного підходу до навчання із застосуванням навчально-дослідницького та інноваційного середовища в ході підготовки випускників спеціальності «Фармацція». Акцентовано увагу на реалізації ідеї міждисциилінарного підходу до навчання разом із сучасними концептуальними підходами до вдосконалення підготовки майбутніх фахівців фармацевтичної галузі, адже він стимулює вдосконалення процесу теоретичного чи практичного заняття; надае студентові розуміння взаємопов'язаності фахових дисичилін, потреби в удосконаленні знань та вмінь задля вирішення ситуаційних завдань у процесі традиційного практичного заняття, на практиці в аптечній установі.

На основі аналізу науково-педагогічних джерел з окресленої проблеми виокремлено ряд характеристик розвивального освітнвого середовища, які слір ураховувати у процесі взаємодіі усіх учасників освітнього процесу задля досягнення циілей навчального закладу та дотримання належних умов надання освітніх послуг, які повинні бути простором для повноцінного розвитку, осередком успішних, креативних і щзасливих людей.

Ці та інші аспекти дозволяють стверджувати про нагальність перегляду традиційних підходів щодо підготовки студентів навчальних закладів; виокремлення нових прийомів, методів, напрямів роботи з ними задля формування конкурентоздатного, висококвалібікованого, готового до змін працівника.

Ключові слова: освітне середовище, розвивальне середовище, інноваційне мислення, фармацевтична галузь, міждисцуиплінарний підхід, освітня діяльність, фактори впливу, дослідницька діяльність, самовдосконалення.

*(C) Аисенко Н. В.

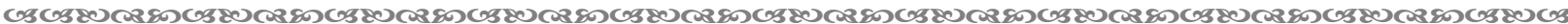
110 